\title{
Cloning and characterization of genes induced by hydrogen peroxide in Bacillus subtilis
}

\author{
Orla M. Hartford and Barbara C. A. Dowds* \\ Department of Biology, St Patrick's College, Maynooth, Co. Kildare, Ireland.
}

(Received 10 February 1992; revised 19 June 1992; accepted 30 June 1992)

\begin{abstract}
Transcriptional fusions of Bacillus subtilis DNA to the $l a c Z$ gene were screened for induction, initially by ethanol and then by hydrogen peroxide $\left(\mathrm{H}_{2} \mathrm{O}_{2}\right)$. Two fusions were identified which were induced late following treatment with sublethal concentrations of $\mathrm{H}_{2} \mathrm{O}_{2}(100 \mu \mathrm{M})$. The $o x y-1$ promoter was induced 4-5-fold and mapped to $11^{\circ}$ while the oxy-2 promoter was induced 20-fold and mapped close to the right of the defective prophage PBSX, at about $120^{\circ}$. The $o x y-2$ fusion was induced by mitomycin $C$ as well as $\mathrm{H}_{2} \mathrm{O}_{2}$, which correlated with the induction of PBSX by these agents. This was probably not a transcriptional induction, but rather a consequence of the induction of PBSX replication extending into adjacent regions of the chromosome.
\end{abstract}

\section{Introduction}

Many studies have reported the adaption of bacteria to a variety of environmental stresses. Bacteria have been shown to adapt to high levels of stress as a result of pretreatments that provoke lesser stress. Such protective inductions can be seen in Bacillus subtilis in response to oxidative stress. Pretreatment of $B$. subtilis with hydrogen peroxide $\left(\mathrm{H}_{2} \mathrm{O}_{2} ; 100 \mu \mathrm{M}\right)$ protects the cells against the otherwise lethal effects of a high concentration (10 mM) of the oxidant (Murphy et. al., 1987; Dowds et al., 1987). The pretreatment leads to an induced synthesis of a number of proteins which may play a protective role against $\mathrm{H}_{2} \mathrm{O}_{2}$.

A regulatory protein OxyR, that has been identified in Salmonella typhimurium and Escherichia coli, induces, in its oxidized form, at least nine genes involved in stress tolerance (Christman et al., 1985; Storz et al., 1990). Among these are the genes encoding glutathione reductase, catalase and an alkyl hydroperoxide reductase. Mutants with deletions of the $\operatorname{oxy} R$ gene, which cannot induce the nine proteins, are sensitive to $\mathrm{H}_{2} \mathrm{O}_{2}$, alkyl hydroperoxide and some redox-cycling agents. Futhermore, a dominant mutation in this gene causes resistance to $\mathrm{H}_{2} \mathrm{O}_{2}$, as well as overexpression of the nine proteins.

Isolation of DNA repair mutants in E. coli has led to some understanding of events following $\mathrm{H}_{2} \mathrm{O}_{2}$ treatment. Among the gene products that are needed by the cell after challenge with $\mathrm{H}_{2} \mathrm{O}_{2}$ are exonuclease III and endonuclease IV (Demple et al., 1986), which restore

\footnotetext{
* Author for correspondence. Tel. 1 6285222; fax 16289432.
}

normal $3^{\prime}$ termini at single strand breaks generated by $\mathrm{H}_{2} \mathrm{O}_{2}$, thus facilitating DNA repair. In addition mutants defective in DNA polymerase I (Ananthaswamy \& Eisenstark, 1977), DNA polymerase III (Hagansee $e t$ al., 1987) and $\operatorname{recA}$ (Carlsson \& Carpenter, 1980) are extremely sensitive to $\mathrm{H}_{2} \mathrm{O}_{2}$. The recA gene acts as a positive regulator of the SOS operon, which is induced following DNA damage in the cell. A similiar repair response, SOB, has been identified in $B$. subtilis, and is regulated by $\mathrm{recA}^{+}$(previously called $\mathrm{rec} E^{+}$and homologous to recA of $E$. coli). A strain carrying the recE4 mutation is sensitive to low concentrations of $\mathrm{H}_{2} \mathrm{O}_{2}$ (Bol \& Yasbin, 1990).

Catalase also plays a role in the protection of bacteria against $\mathrm{H}_{2} \mathrm{O}_{2}$ toxicity. An $E$. coli strain carrying the $k_{a t} G^{+}$plasmid, and consequently containing significantly more catalase, was found to be far more resistant to $\mathrm{H}_{2} \mathrm{O}_{2}$ than a non-plasmid-bearing strain (Eisenstark $\&$ Perrot, 1987). However, these authors also reported that $\operatorname{rec} A, \operatorname{pol} A$ and oxy $\Delta 3$ mutants all had wild-type levels of catalase activity, but much lower survival in response to $\mathrm{H}_{2} \mathrm{O}_{2}$ than a kat mutant with no catalase activity. Thus catalase appears to play a minor role compared with repair enzymes or the range of products regulated by $\operatorname{oxy} R$ in terms of protecting cells against $\mathrm{H}_{2} \mathrm{O}_{2}$. High levels of catalase and superoxide dismutase were found in $B$. subtilis. Whereas it was originally reported that these two enzymes were not induced by $\mathrm{H}_{2} \mathrm{O}_{2}$ (Murphy et al., 1987), a 5-7-fold induction of catalase has been observed recently (J. F. O'Rourke, O. M. Hartford \& B. C. A. Dowds, unpublished). 
In addition to inducing protective genes, $\mathrm{H}_{2} \mathrm{O}_{2}$ has also been reported to induce the release of phage particles from B. subtilis (Stickler et al., 1965).

Genes induced by $\mathrm{H}_{2} \mathrm{O}_{2}$ have not yet been systematically cloned. Kogoma et al. (1988) identified gene fusions in $E$. coli that were induced by superoxide-radicalgenerating drugs. However, these genes were only gradually induced by these agents, and were not induced by $\mathrm{H}_{2} \mathrm{O}_{2}$. Damage-inducible (din) genes were isolated from $B$. subtilis following treatment with mitomycin C. Some of these genes were also induced by concentrations of $\mathrm{H}_{2} \mathrm{O}_{2}(3 \mathrm{mM})$ that were high enough to decrease the survival rate of the cultures (Bol \& Yasbin, 1990). Here we describe the approach we took towards cloning genes of $B$. subtilis induced by low, protective concentrations of $\mathrm{H}_{2} \mathrm{O}_{2}$, and the effects of this oxidant on induction of prophages resident in wild-type strains.

\section{Methods}

Strains. The bacterial strains and plasmids used in this study are listed in Table 1.

Growth of B. subtilis. B. subtilis JH642 and YB886 were inoculated from fresh plate cultures and grown in Schaeffer's medium (SM) (Schaeffer et al., 1965) for $3 \mathrm{~h}$. A $1 \mathrm{ml}$ volume of culture was diluted into $50 \mathrm{ml} \mathrm{SM}$ or minimal medium [Spizizen salts (Anagnostopoulos \& Spizizen, 1961) supplemented with glucose $(0.5 \%)$, L-tryptophan $(0.0025 \%)$ and either L-phenylalanine $(0.0035 \%)$ (JH642) or Lmethionine $(0.004 \%)$ (YB886)] and allowed to grow to early exponential phase. Cultures were treated with different concentrations
$(100 \mu \mathrm{M}-10 \mathrm{mM})$ of $\mathrm{H}_{2} \mathrm{O}_{2}$ at $\mathrm{OD}_{550}=0 \cdot 1$. Optical density readings $\left(\mathrm{OD}_{550}\right)$ of the culture were noted at different stages of the growth cycle.

Induction of protection against oxidative stress. B. subtilis JH642 was grown to $O D_{550}=0.15$ in Luria both (LB) or minimal medium. Aliquots $(1 \mathrm{ml})$ were placed in six test-tubes and treated as shown in Table 2. Treatment times were $30 \mathrm{~min}$ for ethanol and $15 \mathrm{~min}$ for $\mathrm{H}_{2} \mathrm{O}_{2}$. Samples subjected to two treatments were treated sequentially unless stated otherwise.

Screening the bank of gene fusions for induction of $\beta$-galactosidase expression by ethanol. The bank of gene fusions was that assembled by K. Woodson and others (unpublished). (1) Chloramphenicol-resistant $B$. subtilis transformants were plated on: (a) LB plates containing chloramphenicol $\left(5 \mu \mathrm{g} \mathrm{ml}^{-1}\right)$, 5-bromo-4-chloro-3-indolyl- $\beta$-D-galactopyranoside $(\mathrm{X}-\mathrm{Gal})\left(40 \mu \mathrm{g} \mathrm{ml}^{-1}\right)$ and ethanol $(4 \%, \mathrm{v} / \mathrm{v})$, and $(b) \mathrm{LB}$ plates containing chloramphenicol and X-Gal.

(2) Chloramphenicol-resistant transformants that were positive on plates were screened in liquid culture for expression of $\beta$-galactosidase in the presence and absence of $100 \mu \mathrm{M}-\mathrm{H}_{2} \mathrm{O}_{2}$ or $4 \%$ ethanol. Individual transformants were grown at $37^{\circ} \mathrm{C}$ to $\mathrm{OD}_{550}=0 \cdot 1$. Samples $(1 \mathrm{ml})$ of cells were taken at $20 \mathrm{~min}$ intervals after addition of $\mathrm{H}_{2} \mathrm{O}_{2}$, and were centrifuged at $4^{\circ} \mathrm{C}$ for $5 \mathrm{~min}$. The supernatant was then removed by suction and the pellets were frozen at $-20^{\circ} \mathrm{C}$. $\beta$-Galactosidase levels in the pellets were measured according to Ferrari et al. (1986). One unit of $\beta$-galactosidase is defined as the amount of enzyme activity hydrolysing $1 \mathrm{nmol} o$-nitrophenyl galactopyranoside $\min ^{-1}$ at $28^{\circ} \mathrm{C}$.

Cloning of gene fusions in E. coli. High molecular mass DNA was isolated from the fusion strains of $B$. subtilis and digested with a restriction enzyme that cleaved pJM783 just once (in the multiple cloning site in the case of EcoRI or in the lacZ gene in the case of ClaI). The digested DNA was then extracted with phenol and precipitated with ethanol before circularizing the digested fragments by ligating at DNA concentrations of $0 \cdot 1-1 \mathrm{ng} \mu \mathrm{l}^{-1}$ at $15^{\circ} \mathrm{C}$ for $16 \mathrm{~h}$. The circularized

Table 1. Bacterial strains and plasmids

\begin{tabular}{|c|c|c|}
\hline Strain/plasmid & Relevant genotype & Source or reference \\
\hline JH642 & $\operatorname{trpC2}$ pheAl & BGSC \\
\hline SO113 & $\operatorname{trpC2}$ amy-3 & Ortlepp et al. (1983) \\
\hline L8508 & $x h i-1479$ lyt -2 & $\begin{array}{l}\text { D. Karamata, Institut de génétique et } \\
\text { de biologie microbiennes, Lausanne, } \\
\text { Switzerland. }\end{array}$ \\
\hline QB935 (1A8) & aroD120 lys- 1 trpC2 & $\mathrm{BGSC}$ \\
\hline $\begin{array}{l}\text { QB917 (1A10) } \\
\text { QB879 (1A125) }\end{array}$ & $\begin{array}{l}\text { hisAl thr-5 trpC2 } \\
\text { argF4 metA29 thiB4 }\end{array}$ & $\tau^{\mathrm{BOSO}}$ \\
\hline VUB79 (1A158) & metA4 & \\
\hline \multicolumn{3}{|l|}{ E. coli } \\
\hline $5 \mathrm{~K}$ & $h s d R_{\mathrm{k}}^{-}$thi thr leu tonA supE & Hubacek \& Glover (1970) \\
\hline pWD37 & Clones of PBSX & Wood et al. $(1990 a)$ \\
\hline pWD38 & & \\
\hline pWD316 & & \\
\hline
\end{tabular}

* Numbers in parentheses are BGSC (Bacillus Genetic Stock Center, Ohio State University, Columbus, OH, USA) numbers.

$\dagger$ This plasmid was used for the construction of the bank of gene fusions. 
chromosomal DNA was then transformed into $E$. coli $5 \mathrm{~K}$ and ampicillin-resistant transformants were selected.

Genetic mapping. Mapping of the gene fusions was performed by PBS-1 transduction using the $B$. subtilis mapping kit strains (Dedonder et al., 1977) and metA strains (BGSC) as recipients and the fusion strains as donors, and selecting for chloramphenicol resistance. The transduction method described in O'Kane et al. (1985) was used with the following variations. When preparing lysates, bacteria were removed from the lysate supernatant by filtration $(0.45 \mu \mathrm{M}$ Acrodiscs from Gelman Sciences) instead of being killed by chloroform treatment. Transductions were not performed on overnight cultures of the recipient strain. Rather, the cultures were grown in LB until they were in a state of maximum motility (usually at a culture density of $\mathrm{OD}_{550}=0 \cdot 6-0.8$ ). In addition, the recipient strain was incubated with the transducing lysate for $15 \mathrm{~min}$ instead of $20 \mathrm{~min}$.

Other techniques. DNA preparation, restriction enzyme digestion, transformation of $E$. coli, Southern blotting, hybridization and DNA sequencing were as described in Sambrook et al. (1989).

\section{Results}

Induction of protection against $\mathrm{H}_{2} \mathrm{O}_{2}$ by pretreatment with ethanol

Pretreatment of $B$. subtilis JH642 with $50-100 \mu \mathrm{M}-\mathrm{H}_{2} \mathrm{O}_{2}$ for $10 \mathrm{~min}$ protects cells against the lethal effects of $10 \mathrm{~mm}-\mathrm{H}_{2} \mathrm{O}_{2}$ (Murphy et al., 1987; Dowds \& Hoch, 1991). Synthesis of at least six proteins is induced within $5 \mathrm{~min}$ of the $50 \mu \mathrm{M}$ pretreatment. Pretreatment of cultures with ethanol $(4 \%, \mathrm{v} / \mathrm{v})$ for 30 min resulted in an approximately 100 -fold increase in survival in the presence of $10 \mathrm{mM}-\mathrm{H}_{2} \mathrm{O}_{2}$ (Table 2). Ethanol at micromolar concentrations acts as a scavenger of hydroxyl radicals generated by breakdown of $\mathrm{H}_{2} \mathrm{O}_{2}$ (Imlay \& Linn, 1988). Pre-induction of cultures with concentrations of ethanol $(0.001 \%)$ that scavenge radicals did not protect against lethal levels of $\mathrm{H}_{2} \mathrm{O}_{2}$ (data not shown). Cells treated with ethanol $(4 \%)$ and $\mathrm{H}_{2} \mathrm{O}_{2}(10 \mathrm{mM})$ at the same time showed a survival rate similar to those treated only with $10 \mathrm{~mm}-\mathrm{H}_{2} \mathrm{O}_{2}$ (data not shown). Thus ethanol must be added before $\mathrm{H}_{2} \mathrm{O}_{2}$ in order to exert the protective effect. Cultures pretreated with chloramphenicol $\left(100 \mu \mathrm{g} \mathrm{ml}^{-1}\right)$ and ethanol $(4 \%)$ showed little resistance to $\mathrm{H}_{2} \mathrm{O}_{2}$ (data not shown). Protein synthesis appears, therefore, to be essential for the observed protection by ethanol.

\section{Identification of gene fusions induced by ethanol}

Cloning of the oxidative stress genes relied on the observation that cultures pretreated with ethanol are protected against the lethal effects of $\mathrm{H}_{2} \mathrm{O}_{2}$. Thus ethanol seems to induce the genes that protect the cells against $\mathrm{H}_{2} \mathrm{O}_{2}$. Ethanol is more stable than $\mathrm{H}_{2} \mathrm{O}_{2}$ on agar plates so ethanol was used to identify the oxidative stress
Table 2. Survival of B. subtilis JH642 after ethanol and $\mathrm{H}_{2} \mathrm{O}_{2}$ treatments

Samples subjected to two treatments were treated sequentially The values marked $a$ and $b$ were obtained in two different experiments. For reproducibility of this type of data see Murphy $e t$ al. (1987) and Dowds \& Hoch (1991).

\begin{tabular}{lc}
\hline \hline Treatment & Percentage survival \\
\hline Untreated & $100^{a b b}$ \\
$4 \%$ Ethanol & $95^{a}$ \\
$100 \mu \mathrm{M}-\mathrm{H}_{2} \mathrm{O}_{2}$ & $100^{b}$ \\
$10 \mathrm{mM}-\mathrm{H}_{2} \mathrm{O}_{2}$ & $0 \cdot 15^{a}, 0 \cdot 05^{b}$ \\
$4 \%$ Ethanol, then $10 \mathrm{mM}-\mathrm{H}_{2} \mathrm{O}_{2}$ & $15^{a}$ \\
$100 \mu \mathrm{M}$, then $10 \mathrm{mM}-\mathrm{H}_{2} \mathrm{O}_{2}$ & $1 \cdot 8^{b}$ \\
\hline \hline
\end{tabular}

genes. A bank of transcriptional fusions to the lacZ indicator gene was constructed in the integrating plasmid pJM783 (Perego \& Hoch, 1988) by ligating a partial Sau3A digest of $B$. subtilis chromosomal DNA to BamHI-cut pJM783 DNA. The B. subtilis chromosomal DNA fragments were thus inserted at the $5^{\prime}$ end of the promoterless $l a c Z$ gene on the plasmid, placing the lac $Z$ gene under the control of a promoter in the insertion. pJM783 also contains a chloramphenicol-resistance gene which functions in $B$. subtilis, a gene which confers ampicillin resistance to $E$. coli and an origin of replication for $E$. coli but not for $B$. subtilis. Thus after transformation into $B$. subtilis $\mathrm{JH642}$, the recombinant plasmid must integrate in order to be maintained.

Transformants were grown on medium containing chloramphenicol to select for integrants, ethanol to induce the gene fusions and $\mathrm{X}$-gal, the chromogenic substrate of $\beta$-galactosidase. Blue colonies (i.e. those expressing $\beta$-galactosidase) were then streaked on $\mathrm{X}-\mathrm{Gal}$ plates in the presence and absence of ethanol. Out of a total of 12000 chloramphenicol-resistant colonies, 108 were blue in the presence of ethanol and white in its absence on agar plates. Each of these colonies was tested in liquid medium with additions of inducing non-lethal levels of $\mathrm{H}_{2} \mathrm{O}_{2}(100 \mu \mathrm{M})$. Three of the 108 ethanolinduced colonies were found to be induced by $\mathrm{H}_{2} \mathrm{O}_{2}$ in liquid culture. Two of these were later found to be different isolates of the same gene (oxy-2). Thus a total of two different gene fusions was detected by this method.

\section{Induction with $\mathrm{H}_{2} \mathrm{O}_{2}$}

$\beta$-Galactosidase activity increased significantly in two gene fusions when cells were incubated in the presence of $100 \mu \mathrm{M}-\mathrm{H}_{2} \mathrm{O}_{2}$. These fusions showed different patterns of $\beta$-galactosidase activity. The $o x y-1$ fusion was induced 4-5-fold (Fig. 1a) and showed a continuous increase in $\beta$-galactosidase activity throughout the growth cycle, with induction being first observed about $75 \mathrm{~min}$ after 


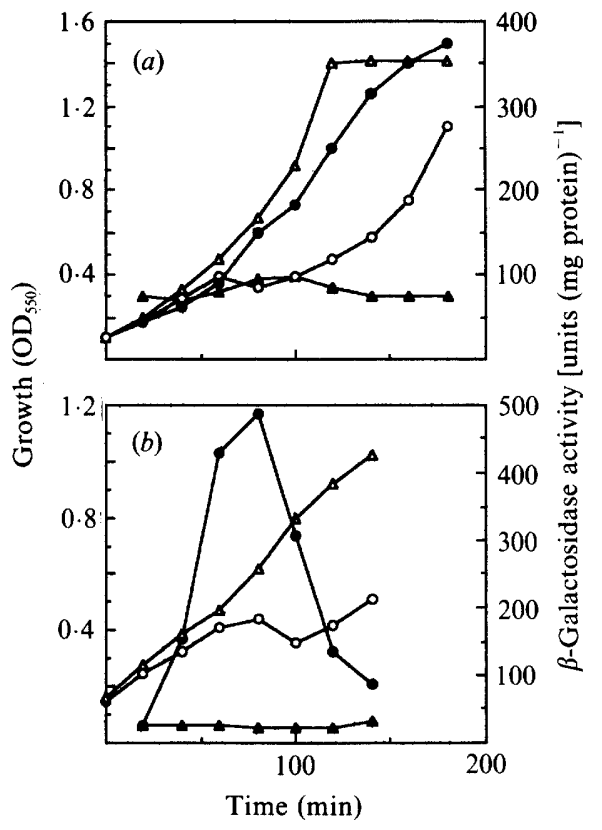

Fig. 1. Growth ( $\left(\mathrm{OD}_{550}\right.$; open symbols) and $\beta$-galactosidase specific activity (filled symbols) of $B$. subtilis strains JH642: :oxy-1 $(a)$ and JH642: :oxy-2 (b) in the absence $(\triangle, \Delta)$ or presence $(O, O)$ of $\mathrm{H}_{2} \mathrm{O}_{2}$ (100 $\mu \mathrm{M}$, added at time zero).

addition of $\mathrm{H}_{2} \mathrm{O}_{2}$. The second pattern of $\beta$-galactosidase expression, seen for the oxy-2 fusion (Fig. $1 b$ ), showed a sharp increase followed by a decline in specific activity peaking at 80 min following treatment with $\mathrm{H}_{2} \mathrm{O}_{2}$. The $o x y-2$ fusion was maximally induced 20 -fold by $100 \mu \mathrm{M}$ $\mathrm{H}_{2} \mathrm{O}_{2}$.

\section{Effect of $\mathrm{H}_{2} \mathrm{O}_{2}$ on the growth of $\mathrm{B}$. subtilis}

Peak induction of the oxy-2 clone occurred shortly after the time at which low concentrations of $\mathrm{H}_{2} \mathrm{O}_{2}$ began to affect the growth of cultures of $B$. subtilis strain $\mathrm{JH} 642$ (Fig. $2 a$ ). About 60 min after addition of $100 \mu \mathrm{M}-\mathrm{H}_{2} \mathrm{O}_{2}$ the culture density declined before growth resumed, 20$40 \mathrm{~min}$ later. The decrease in the culture density did not occur when catalase was added simultaneously with $\mathrm{H}_{2} \mathrm{O}_{2}$, but did occur when catalase was added at the actual time of the decrease. This suggests that killing of the cells and induction of $\beta$-galactosidase in the clones is mediated not by $\mathrm{H}_{2} \mathrm{O}_{2}$ but by a product of the action of $\mathrm{H}_{2} \mathrm{O}_{2}$ on the cells, produced after about $60 \mathrm{~min}$.

Most strains of $B$. subtilis 168 (including JH642) contain two defective prophages: SP $\beta$ and PBSX (Warner et al., 1977; Seaman et al., 1964). It has been shown that $\mathrm{H}_{2} \mathrm{O}_{2}(440 \mu \mathrm{M})$ induces phages in $B$. subtilis (Stickler et al., 1965). Strain YB886, which has been cured of SP $\beta$ and rendered non-inducible for PBSX (Yasbin et al., 1980), was tested for its response to $\mathrm{H}_{2} \mathrm{O}_{2}$.
This strain did not display the dip in the growth curve characteristic of strain JH642 when treated with $\mathrm{H}_{2} \mathrm{O}_{2}$ (Fig. 2b). This suggests that one or both of the two prophages is being induced by $\mathrm{H}_{2} \mathrm{O}_{2}$ in $B$. subtilis $\mathrm{JH} 642$. When PBSX was disrupted in JH642 with an integrating plasmid containing a fragment from the centre of the late operon (pWD37 from Wood et al., 1990a), the dip in the growth curve following treatment with $\mathrm{H}_{2} \mathrm{O}_{2}(250 \mu \mathrm{M})$ was not observed (Fig. $3 a$ ). This implies that the dip observed in JH642 (PBSX intact) after treatment with low concentrations of $\mathrm{H}_{2} \mathrm{O}_{2}$ is caused by PBSX and not by other prophages such as SP $\beta$. However, another phage (possibly SP $\beta$ ) may be induced by high concentrations of $\mathrm{H}_{2} \mathrm{O}_{2}$ since a $1 \mathrm{mM}$ treatment did cause a dip in the growth curve of JH642::pWD37 (Fig. 3b). The kinetics of cell lysis were different in this case, lysis peaking at $130 \mathrm{~min}$ instead of the $80 \mathrm{~min}$ observed for PBSX.

\section{Induction with mitomycin $C$}

The correlation between induction of phages and induction of the gene fusions by $\mathrm{H}_{2} \mathrm{O}_{2}$ suggested that the gene fusions might contain phage genes. We tested this further by assessing their induction by mitomycin $\mathrm{C}$, which has been reported to induce phages PBSX and SP $\beta$ (Warner et al., 1977) as well as the SOB response (O'Kane et al., 1986). Mitomycin C (0·1, 1 and $3 \mu \mathrm{g} \mathrm{ml}^{-1}$ ) was added to an early exponential phase culture of $\mathrm{JH} 642$ and was found to cause a decline in the density of the culture, starting at about $80 \mathrm{~min}$. The density of the culture stabilized at about $110 \mathrm{~min}$ but growth was not resumed (data not shown). This dip was also found during growth of JH642::pWD37 in the presence of mitomycin $\mathrm{C}$ (data not shown), thus suggesting that mitomycin $\mathrm{C}$ induces other phages in addition to PBSX. $\beta$-Galactosidase expression was induced by mitomycin $C$ in oxy-2 (Fig. 4) but not in the oxy-1 clone (data not shown), suggesting that the gene present in oxy-2 might be a phage gene while the $o x y-1$ gene is not.

\section{Isolation of gene fusions}

In order to isolate the $\mathrm{H}_{2} \mathrm{O}_{2}$-inducible promoters, DNA was prepared from the fusions strains of $B$. subtilis. The chromosomal DNA was cleaved with EcoRI (which cuts pJM783 in the multiple cloning site) and the fragments were then circularized by ligation at low DNA concentration and transformed into $E$. coli, where pJM783 can replicate. Plasmid DNA was prepared from ampicillinresistant transformants and was treated with SalI and EcoRI (which cut the insert from pJM783). This treatment revealed a $2.3 \mathrm{~kb}$ insert for the oxy-2 clone, 


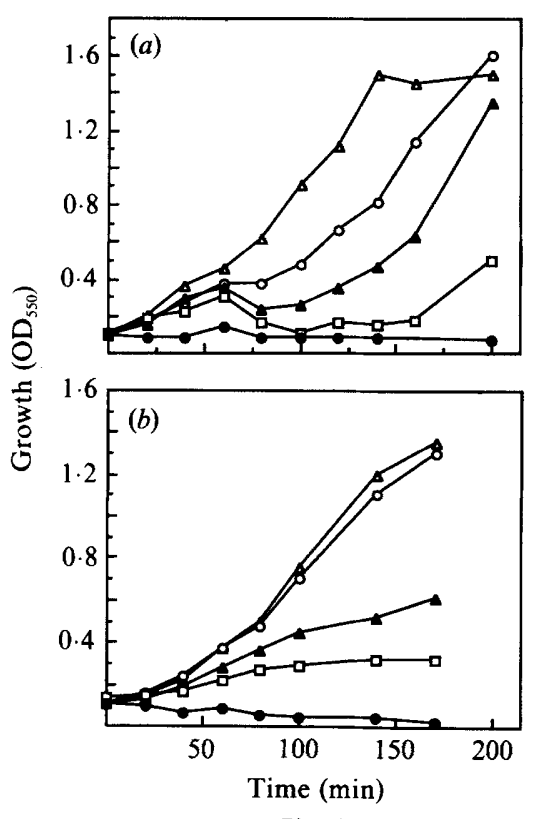

Fig. 2
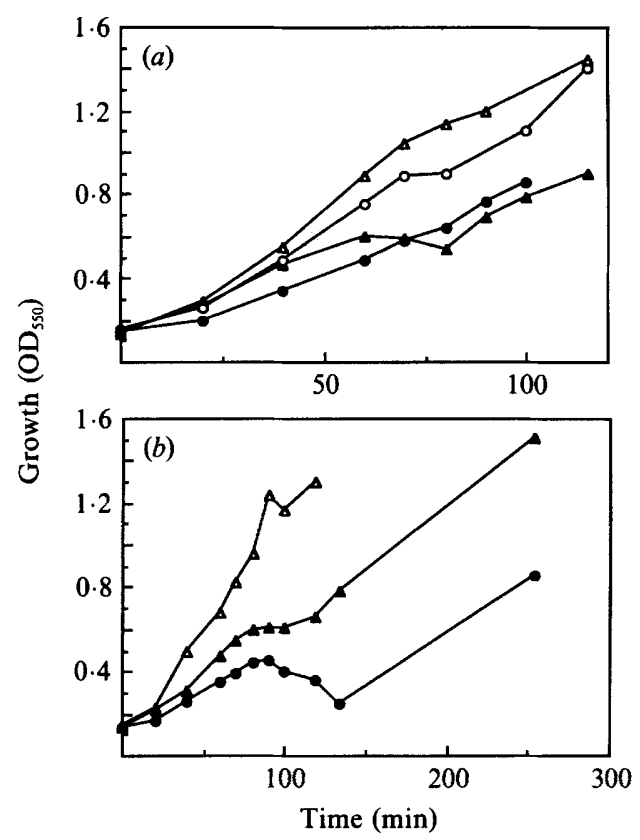

Fig. 3

Fig. 2. Effect of $\mathrm{H}_{2} \mathrm{O}_{2}$ concentration on the growth $\left(\mathrm{OD}_{550}\right)$ of $B$. subtilis strains JH642 (a) and YB886 (b). $\mathrm{H}_{2} \mathrm{O}_{2}$ was added to cultures in early exponential phase at the following concentrations: $\triangle$, zero; $\bigcirc, 50 \mu \mathrm{M}$ for $(a) 200 \mu \mathrm{M}$ for $(b) ; \Delta, 100 \mu \mathrm{M}$ for $(a), 500 \mu \mathrm{M}$ for $(b) ; \square$, $200 \mu \mathrm{M}$ for $(a), 1 \mathrm{mM}$ for $(b) ; 0,10 \mathrm{mM}$ for $(a)$ and $(b)$.

Fig. 3. Effects of $\mathrm{H}_{2} \mathrm{O}_{2}$ on the growth of $B$. subtilis strain JH642: :pWD37. (a) Comparison with the control strain JH642. $\triangle$, $\Delta$, JH642; O, JH642::pWD37. Open symbols, absence of $\mathrm{H}_{2} \mathrm{O}_{2}$; filled symbols, $250 \mu \mathrm{M}-\mathrm{H}_{2} \mathrm{O}_{2}$. (b) Effect of $\mathrm{H}_{2} \mathrm{O}_{2}$ concentration on strain JH642: :pWD37. $\triangle$, zero; $\triangle, 500 \mu \mathrm{M} ; \bigcirc, 1 \mathrm{mM} \mathrm{H}_{2} \mathrm{O}_{2}$ was added at time zero.

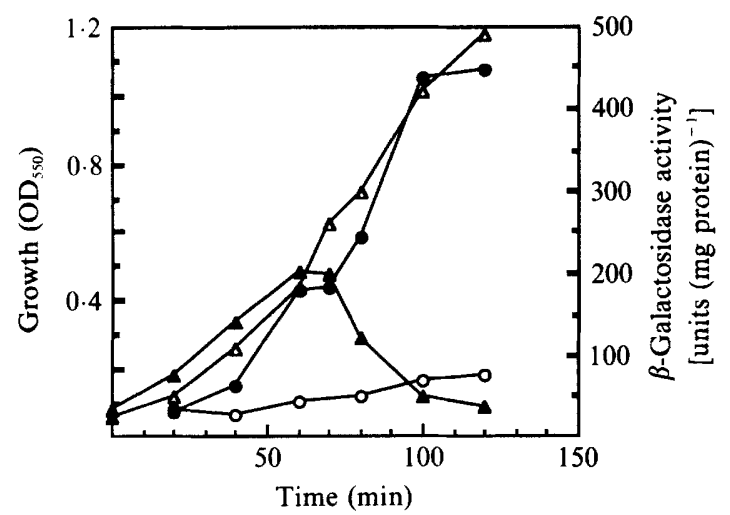

Fig. 4. Growth $\left(\mathrm{OD}_{550} ; \Delta, \Delta\right)$ and $\beta$-galactosidase activity $(O, O)$ of $B$. subtilis strain JH642::oxy-2 in the absence (open symbols) or presence (filled symbols) of mitomycin $\mathrm{C}\left(0.1 \mu \mathrm{g} \mathrm{ml}^{-1}\right.$; added at time zero).

whereas the insert of $o x y-1$ was apparently deleted during cloning. Chromosomal DNA from JH642 : : oxy-1 was then digested with $\mathrm{ClaI}$ (which cuts pJM783 once, within the lac $Z$ gene), and the fragments were ligated and transformed into $E$. coli $5 \mathrm{~K}$. By gel analysis, it was shown that the insert size in the oxy-1 clone was approximately $1.7 \mathrm{~kb}$. Plasmid DNA was prepared on a large scale from the positive clones and analysed with various restriction enzymes. The restriction maps differ for the two clones (data not shown), implying that the clones represent two different genes. A second isolate of the gene in the $o x y$-2 clone was also found, as determined by restriction mapping, partial sequencing and induction characteristics (data not shown).

\section{Induction of oxy-2 in YB886}

In order to further investigate whether the $o x y$-2 gene was derived from PBSX, the clone was transformed into YB886 and its induction was assessed in this strain. After transformation of the $o x y-2$ clone into YB886, chloramphenicol-resistant colonies were obtained. Thus we can conclude that the $B$. subtilis gene in oxy-2 is not located in $\mathrm{SP} \beta$, which is deleted in YB886 and is therefore not available for recombination with an SP $\beta$ gene fusion. The gene fusion was not induced by $\mathrm{H}_{2} \mathrm{O}_{2}$ in YB886 as expected if it is part of one of the PBSX operons, since the prophage is uninducible in this strain. This result appeared to confirm that the $o x y-2$ gene is part of PBSX. However, it was also noted that the level of uninduced synthesis of $\beta$-galactosidase is zero in this strain compared to an appreciable level of uninduced synthesis 
Table 3. Mapping of oxy-1

The donor strain was JH642: :oxy-1.

\begin{tabular}{cll}
\hline \hline $\begin{array}{c}\text { Recipient strain } \\
\text { (BGSC no.) }\end{array}$ & Marker & $\begin{array}{l}\text { Percentage cotransduction } \\
\text { with Cm }\end{array}$ \\
\hline 1A3 & purA26 & 19,21 \\
& cysA14 & 98,100 \\
1A5 & glyB133 & 0 \\
& metC5 & 0 \\
1A8 & lys-1 & 0 \\
aroD120 & 0 \\
1A10 & thr-5 & 0 \\
& hisA1 & 0 \\
\hline \hline
\end{tabular}

in JH642 (Fig. 1b). It was similarly noted that the level of uninduced and induced synthesis was zero in another wild-type strain, SO113, and in a strain, L8508, in which PBSX is heat-inducible. This suggested that possibly the clone had integrated into these strains at a different site from the one at which the fusion had been located in JH642. Thus the position of the inserted plasmid was determined in these strains and was found to be at approximately the same location in all three [frequency of cotransduction with $m e t C=52 \% \quad(\mathrm{JH} 642), 45 \%$ (YB886) and 55\% (SO113)]. The difference in the level of uninduced synthesis of $\beta$-galactosidase might possibly be caused by the promoter for this particular gene being absent in YB886, SO113 and L8508.

\section{Hybridization to $P B S X$ region}

pWD316, 38, 37, 35, 31 and a possible repressor fragment (Wood et al., 1990a, b) are clones of fragments of PBSX. Clones pWD38, 37, 35 and 31 span most of the late operon of PBSX, while the other two clones are probably derived from the early operon. These clones were Southern blotted and hybridized to the oxy-2 probe. $o x y$-2 failed to hybridize to any of these fragments. Thus if the $o x-2$ gene is part of PBSX, it is probably located within a part of the phage genome that has not yet been cloned.

\section{Genetic mapping}

The oxy-1 gene mapped very close to cys $A 14$ at $11^{\circ}$. It displayed $99 \%$ and $20 \%$ cotransduction with the cys $A 14$ and purA26 markers respectively (Table 3 ).

The gene fused to $l a c Z$ in $o x y-2$ was mapped relative to $m e t C$ and $m e t A$ and compared with similar mapping data from clones representing the late operon of PBSX. The data (Table 4) show that oxy-2 maps closer to metC than to metA. It cannot be located between these two genes, i.e. in the PBSX genome, since the PBSX marker pWD37 (Wood et al., 1990a) is closely linked to both
Table 4. Mapping of oxy-2 and pWD37

\begin{tabular}{|c|c|c|}
\hline $\begin{array}{l}\text { Recipient strain } \\
\text { (BGSC no.) }\end{array}$ & Marker & $\begin{array}{l}\text { Percentage cotransduction } \\
\text { with } \mathrm{Cm}^{\mathrm{r}}\end{array}$ \\
\hline \multicolumn{3}{|c|}{ (a) oxy-2 (donor strain JH642: :oxy-2) } \\
\hline \multirow[t]{2}{*}{$1 \mathrm{~A} 3$} & purA26 & 0 \\
\hline & cysA14 & 0 \\
\hline \multirow[t]{2}{*}{$1 \mathrm{~A} 5$} & metC5 & $55,46,54,54$ \\
\hline & glyB133 & 0 \\
\hline \multirow[t]{2}{*}{$1 \mathrm{~A} 8$} & lys-1 & 0 \\
\hline & aroD120 & 0 \\
\hline $1 \mathrm{~A} 125$ & metA29 & $3 \cdot 6$ \\
\hline $1 \mathrm{~A} 158$ & $\operatorname{met} A 29$ & 3.0 \\
\hline \multicolumn{3}{|c|}{ (b) pWD37 (donor strain JH642: :pWD37) } \\
\hline $1 \mathrm{~A} 5$ & $\operatorname{met} C 5$ & 74 \\
\hline $1 \mathrm{~A} 125$ & metA29 & 49 \\
\hline $1 \mathrm{~A} 158$ & metA29 & 51 \\
\hline
\end{tabular}

met $C$ and met $A$ (Table 4). This implies that the oxy-2 gene maps to the right of the $m e t C$ gene and it is therefore close to, but not part of the PBSX genome. It is at a similar distance to the right of metC as pWD37 is to the right of met $A$, i.e. it maps at about $120^{\circ}$.

\section{Discussion}

In this paper, we describe the cloning of two genes induced by $\mathrm{H}_{2} \mathrm{O}_{2}$. The two fusions display different induction kinetics with respect to the time of $\mathrm{H}_{2} \mathrm{O}_{2}$ addition. oxy- 1 clone induction begins about $75 \mathrm{~min}$ after $\mathrm{H}_{2} \mathrm{O}_{2}$ addition and gene fusion expression continues to rise up to $180 \mathrm{~min}$ post addition of the oxidant. Induction of the $o x y-2$ fusion occurs immediately, peaks at $80 \mathrm{~min}$ and then declines.

Genetic mapping places the $o x y-1$ fusion very close to the cys $A$ gene ( $99 \%$ cotransduction) at about $11^{\circ}$ on the $B$. subtilis chromosome. The gene in the vicinity that appears most relevant is the $\operatorname{rec} P$ gene which maps at $10 \cdot 5^{\circ}$. Mutations in this gene render the cell sensitive to mitomycin $\mathrm{C}$, suggesting that the gene may be involved in repairing DNA damage caused by this agent. However, we found that oxy-1 is not induced by mitomycin $\mathrm{C}$, suggesting that this fusion is unlikely to be $r e c P$. A partial sequence of $o x y-1$ (300 nucleotides) did not display homology to any sequences in the GenBank data base (data not shown).

The $o x y-2$ gene displays many of the features expected of a gene in the PBSX prophage genome. We found that this defective prophage is induced by $\mathrm{H}_{2} \mathrm{O}_{2}$ as is the $o x y-2$ clone. In addition, the clone was induced by mitomycin $\mathrm{C}$ and it has been reported that PBSX is also induced by this agent (Warner et al., 1977). However, we found that $o x y-2$ did not hybridize to any of the clones that span the late operon of PBSX and that a 170 
nucleotide partial sequence of $o x y-2$ was not homologous to any sequence in the GenBank database. Mapping of the oxy-2 fusion located it to the right of PBSX and metC $\left(118^{\circ}\right)$. It has been reported that the metC marker is present in multiple copies in cells induced for PBSX replication, suggesting that replication of PBSX extends into adjacent regions of the chromosome (Thurm \& Garro, 1975). Thus it is probable that the observed induction of $o x y-2$ by $\mathrm{H}_{2} \mathrm{O}_{2}$ and mitomycin $\mathrm{C}$ is actually induction of replication rather than transcription, and that it occurs as a secondary effect following induction of PBSX replication by these agents.

A second isolate of the $o x y-2$ gene fusion was obtained during the initial screening. It was shown to be the same as $o x y-2$ based on the kinetics of induction, restriction mapping and partial sequencing (data not shown). The fact that we obtained two isolates of one gene suggests that we identified most of the genes which are induced by $\mathrm{H}_{2} \mathrm{O}_{2}$ and which can be identified by means of gene fusion technology. Using these methods, we were unable to clone the genes which are induced immediately following addition of low concentrations of $\mathrm{H}_{2} \mathrm{O}_{2}$, and which are probably involved in protecting the cells against high concentrations of the oxidant. The gene fusion approach is probably insufficiently sensitive to find genes which are induced transiently $(10-35 \mathrm{~min}$ in this case; Murphy et al., 1987). We have now isolated a $\mathrm{H}_{2} \mathrm{O}_{2}$-resistant mutant which constitutively accumulates high levels of the proteins induced immediately following addition of $\mathrm{H}_{2} \mathrm{O}_{2}$. We have obtained $\mathrm{N}$-terminal sequence information on these proteins which has allowed us to design probes to clone the 'protective' genes (O. M. Hartford \& B. C. A. Dowds, unpublished).

We thank Ms Sheila Morgan for isolating the oxy-2 clone, Dr Heather Wood for the PBSX clones and Dr Anne Moir for advice on transduction. The work was supported by Eolas, the Irish Science and Technology Agency.

\section{References}

Anagnostopoulos, C. \& Spizizen, J. (1961). Requirements for transformation in Bacillus subtilis. Journal of Bacteriology 81, 741746.

ANanthaswamy, H. N. \& Eisenstark, A. (1977). Repair of hydrogen peroxide-induced single stranded breaks in Escherichia coli deoxyribonucleic acid. Journal of Bacteriology 130, 187-191.

Bol, D. K. \& YASBIN, R. E. (1990). Characterization of an inducible oxidative stress system in Bacillus subtilis. Journal of Bacteriology 172, 3503-3506.

Carlsson, J. \& Carpenter, V. S. (1980). The recA gene product is more important than catalase and superoxide dismutase in protecting Escherichia coli against hydrogen peroxide toxicity. Journal of Bacteriology 142, 319-321.

Christman, M. F., Morgan, R. W., Jacobson, F. S. \& Ames, B. N. (1985). Positive control of a regulon for defenses against oxidative stress and some heat-shock proteins in Salmonella typhimurium. Cell 41, 753-762.
Dedonder, R. A., Lepesant, J. A., Lepesant-Kejzlarova, J., Billault, A., Steinmetz, M. \& Kunst, F. (1977). Construction of a kit of reference strains for rapid genetic mapping in Bacillus subtilis 168. Applied and Environmental Microbiology 33, 989-993.

Demple, B., Johnson, A. \& Fung, D. (1986). Exonuclease III and endonuclease IV remove 3 ' blocks from DNA synthesis primers in $\mathrm{H}_{2} \mathrm{O}_{2}$-damaged Escherichia coli. Proceedings of the National Academy of Sciences of the United States of America 83, 7731-7735.

DowDs, B. C. A. \& Hoch, J. A. (1991). Regulation of the oxidative stress response by the hpr gene in Bacillus subtilis. Journal of General Microbiology 137, 1121-1125.

Dowds, B. C. A., Murphy, P., McConnell, D. J. \& Devine, K. M. (1987). Relationship among oxidative stress, growth cycle, and sporulation in Bacillus subtilis. Journal of Bacteriology 169, 57715775.

Eisenstark, A. \& Perrot, G. (1987). Catalase has only a minor role in protection against near-ultraviolet radiation damage in bacteria. Molecular and General Genetics 207, 68-72.

Ferrari, E., Howard, S. M. \& Hoch, J. A. (1986). Effect of stage 0 sporulation mutations on subtilisin expression. Journal of Bacteriology 166, 173-179.

Hagensee, M. E., Bryan, S. K. \& Moses, R. E. (1987). DNA polymerase III requirement for repair of DNA damage caused by methyl methanesulfonate and hydrogen peroxide. Journal of Bacteriology 169, 4608-4613.

HubaceK, J. \& Glover, S. W. (1970). Complementation analysis of temperature-sensitive host specificity mutations in Escherichia coli. Journal of Molecular Biology 50, 111-127.

IMLAY, J. A. \& LINN, S. (1988). DNA damage and oxygen radical toxicity. Science 240, 1302-1309.

Kogama, T., FarR, S. B., Joyce, K. M. \& Natvig, D. O. (1988). Isolation of gene fusions ( $(s o l::$ lacZ) inducible by oxidative stress in Escherichia coli. Proceedings of the National Academy of Sciences of the United States of America 85, 4799-4803.

MurPhy, P., Dowds, B., MCConnell, D. J. \& Devine, K. M. (1987). Oxidative stress and growth temperature in Bacillus subtilis. Journal of Bacteriology 169, 5766-5770.

O'Kane, C., Cantwell, B. A. \& McConnell, D. J. (1985). Mapping of the gene for endo- $\beta$-1,3-1,4-glucanase of Bacillus subtilis. FEMS Microbiology Letters 29, 135-139.

O'KANE, C., StePhens, M. A. \& MCConnell, D. J. (1986). Integrable alpha-amylase plasmid for generating transcriptional fusions in Bacillus subtilis. Journal of Bacteriology 168, 973-981.

Ortlepp, S. A., Ollington, J. F. \& McConnell, D. J. (1983). Molecular cloning in Bacillus subtilis of a Bacillus licheniformis gene encoding a thermostable alpha-amylase. Gene 23, 267-276.

PERGo, M. \& HoCH, J. A. (1988). Sequence analysis and regulation of the hpr locus, a regulatory gene for protease production and sporulation in Bacillus subtilis. Journal of Bacteriology 170, 25602567.

Sambrook, J. Fritsch, E. F. \& Maniatis, T. (1989). Molecular Cloning : a Laboratory Manual, 2nd edn. Cold Spring Harbor, NY: Cold Spring Harbor Laboratory.

Schaeffer, P., Millet, J. \& AuberT, J.-P. (1965). Catabolic repression of bacterial sporulation. Proceedings of the National Academy of Sciences of the United States of America 54, 704711.

Seaman, E., Tarmy, E. \& Marmur, J. (1964). Inducible bacteriophages of Bacillus subtilis. Biochemistry 3, 607-613.

Stickler, D. J., TUCKer, R. G. \& KAY, D. (1965). Bacteriophage-like particles released from Bacillus subtilis after induction with hydrogen peroxide. Virology 26, 142-145.

Storz, G., TARTAGlia, L. A. \& AmEs, B. N. (1990). Transcriptional regulator of oxidative stress-inducible genes: direct activation by oxidation. Science 248, 189-194.

THURM, P. \& GARRo, A. J. (1975). Isolation and characterization of prophage mutants of the defective Bacillus subtilis bacteriophage PBSX. Journal of Virology 16, 184-191.

Warner, F. D., Kitos, G. A., Romano, M. P. \& Hemphill, H. E. (1977). Characterization of $\operatorname{SP} \beta$ : a temperate bacteriophage from Bacillus subtilis 168M. Canadian Journal of Microbiology 23, 45-51. 
Wood, H. E., Dawson, M. T., Devine, K. \& McConnell, D. J. (1990a). Characterization of PBSX, a defective prophage of Bacillus subtilis. Journal of Bacteriology 172, 2667-2674.

Wood, H. E., Devine, K. M. \& MCConnell, D. J. (1990b). Characterization of a repressor gene (xre) and a temperature- sensitive allele from the Bacillus subtilis prophage, PBSX. Gene 96, 83-88.

Yasbin, R. E., Fields, P. I. \& ANDERSEn, B. J. (1980). Properties of Bacillus subtilis 168 derivatives freed of their natural prophages. Gene 12, 155-159. 